\title{
DIGITAL MONITORING OF MYCELIUM GROWTH KINETICS AND VIGOR OF SHIITAKE (LENTINULA EDODES (BERK.) PEGLER) ON AGAR MEDIUM
}

\author{
Renato Mamede de Castro Montini ${ }^{1}$; José Raimundo de Souza Passos ${ }^{2 *}$; Augusto Ferreira da Eira ${ }^{1}$ \\ ${ }^{1}$ Departamento de Produção Vegetal, Faculdade de Ciências Agronômicas, Universidade Estadual Paulista, Botucatu, SP, Brasil; \\ ${ }^{2}$ Departamento de Bioestatística, Instituto de Biociências, Universidade Estadual Paulista, Botucatu, SP, Brasil.
}

Submitted: July 12, 2004; Approved: February 22, 2006

\begin{abstract}
The mycelium growth kinetics and vigor of shiitake (Lentinula edodes (Berk.) Pegler) strains LE 96/17, LE 98/ 51, LE 98/53, and LE 98/56 were studied under different agar medium compositions. The strains were from the mycological collection of the Módulo de Cogumelos, Faculdade de Ciências Agronômicas, Unesp-Botucatu, Brazil. Mycelium fragments from stock cultures were transferred to Petri dishes with Sawdust extract-DextroseAgar medium. The area of growth and vigor (density) of the mycelia were daily recorded with a digital camera, during incubation, until the complete colonization of the Petri dish. The images were analyzed by the freeware UTHSCSA ImageTool, v. 2.0, developed by the University of Texas Health Science Center, San Antonio. The kinetics of mycelium growth, as measured by the mycelium area $\left(\mathrm{mm}^{2}\right)$, has as a deterministic component an exponential function of Gompertz. The vigor, as evaluated by mycelium color in gray scale, was similar for all strains, reached a maximal value between the 4th and 5th day of incubation and decreased further on. The velocity of growth of $L$. edodes strains was lower in enriched culture media, while vigor was higher. Digital monitoring permits a objective evaluation of the growth kinetics of L. edodes in vitro.
\end{abstract}

Key words: Lentinula edodes, shiitake, substrate, mycelium growth, strains.

\section{INTRODUCTION}

Filamentous fungi growth has been estimated by measuring the radial growth of hyphae in solid culture media over time. Growth rates vary under different environmental conditions, thus there is a pursuit for the most suitable conditions for filamentous fungal growth (4). In experimental conditions, solid culture media (agar) may be considered adequate because in the wild, fungi usually benefit from solid material such as wood substrates, animal or vegetable tissue remnants, or soil (5). Mycelial growth on semisolid media can be quantified by area, volume $(5,13)$ or average radius measurements $(3)$.

The microbial biomass growth over a period of time results in a typical sigmoidal curve, which may be divided into several phases with characteristic physiological properties. The first phase is named lag-phase and is characterized by smaller growth rates; the second phase is the exponential, characterized by a constant and maximal growth rate; the third phase depicts the decline of growth rates and is sometimes regarded as a stationary phase of short duration, which is followed by the fourth and last phase, that of death.

The duration of the lag-phase depends on the nature of the inoculum and the nutrients available in culture media. The exponential phase is strongly affected by nutritional supplements as nitrogen and carbon sources. The declining growth rate phase occurs due to the exhaustion of some ratelimiting nutrients or by the accumulation of toxic metabolites. Finally, the death phase is usually followed by autolysis $(5,17)$. Oxygen concentration and $\mathrm{pH}$ influence fugal metabolic processes and, consequently, their ability to make use of nutritional substances as carbon, nitrogen, vitamins, and minerals $(4,6)$ state that the best mycelial growth, as measured by the diameter of $L$. edodes mycelium in culture media, occurred under $\mathrm{pH} 5$. The accumulation of toxic final products and the production of secondary metabolites also influence growth (11).

*Corresponding Author. Mailing address: UNESP, IB, Departamento de Bioestatística, Rubião Junior. 18618-000, Botucatu, SP, Brasil. Fax: (+5514) 3815-3744. E-mail: jrpassos@ibb.unesp.br 
Nevertheless, we find it has been difficult to analyze microbial biomass by vigor of growth, as a consequence of vertical growth and the density of hyphae. We have previously attempted to assess this subjectively by applying classes to the radial growth multiplied by vigor $(8,14)$. In the present study we sought to study the interaction between Lentinula edodes (Berk.) Pegler (10) strains and culture media using digital monitoring by determining the kinetics and vigor of mycelium growth by a precise and repetitive manner.

\section{MATERIALS AND METHODS}

The experiments were carried out in the laboratories of the Módulo de Cogumelos of the Departamento de Produção Vegetal of the Faculdade de Ciências Agronômicas, Unesp, Campus de Botucatu, Area of Biotechnology and Agricultural Microbiology, Botucatu, SP, Brazil (Latitude 22 $2^{\circ} 1^{\prime}$ South, Longitude $48^{\circ} 27^{\prime}$ West and altitude $=786 \mathrm{~m}$ ).

\section{Origin of isolates}

The L. edodes strain LE 96/17, according to the producer was from Israel and cultivated on logs. The strains LE 98/51 (originated from U.S.A., according to the producer), LE $98 / 53$ (according to the producer, originated from Japan), and LE 98/56 (isolated in Taiwan by Mr. Yeh Wen Sheng) were used for axenic cultivation, being all derived from the mycological collection of the Faculdade de Ciências Agronômicas, Universidade Estadual Paulista, Brazil. These lineages present different genotypes, as revealed by RAPD (random amplification of polimorphic DNA) (9).

\section{Culture Media}

The composition (dry matter) of culture media SDA-20, SDA40, SBDA-20, and SBDA-40 was respectively: $156 \mathrm{~g}$ of sawdust (SW), $20 \mathrm{~g}$ of wheat bran (WB), $20 \mathrm{~g}$ of rice bran (RB), and $4 \mathrm{~g}$ of calcium carbonate (CC); $116 \mathrm{~g} \mathrm{SW}, 40 \mathrm{~g} \mathrm{WB}, 40 \mathrm{~g} \mathrm{RB}$, and $4 \mathrm{~g}$ $\mathrm{CC} ; 116 \mathrm{~g} \mathrm{SW}, 40 \mathrm{~g}$ of sugar cane bagasse (SC), $20 \mathrm{~g} \mathrm{WB}, 20 \mathrm{~g}$ $\mathrm{RB}$, and $4 \mathrm{~g} \mathrm{CC}$; and $86 \mathrm{~g} \mathrm{SW}, 30 \mathrm{~g} \mathrm{SC}, 40 \mathrm{~g} \mathrm{WB}, 40 \mathrm{~g} \mathrm{RB}$, and 4 $\mathrm{g} \mathrm{CC}$. All substrates were prepared in $1 \mathrm{~L}$ of boiling water during $15 \mathrm{~min}$, filtered in cotton, supplemented with $10 \mathrm{gL}^{-1}$ of dextrose and $15 \mathrm{gL}^{-1}$ of agar, filled to $1 \mathrm{~L}$ with $\mathrm{dH}_{2} \mathrm{O}$, if necessary, and finally autoclaved at $1 \mathrm{Kgf} / \mathrm{cm}^{2}\left(121^{\circ} \mathrm{C}\right)$ for $30 \mathrm{~min}$.

\section{Shiitake strain inoculation}

The culture media in Duran glass vials $(1000 \mathrm{~mL})$ was poured on Petri dishes under laminar flow and after complete solidification, the four strains were inoculated in all culture media, in order to enhance fungus adaptation to nutrients and diminish the interference of unknown factors during data collection. As soon as the mycelium reached the approximate distance of 10 $\mathrm{mm}$ from the dish's perimeter, it was transferred to a new dish with exactly the same media, under laminar flow, in order to conduct the measurements of mycelium growth. For mycelia transferring we used a circular cutter (5-mm diameter) to cut colonized media, at the colony border, and with the aid of a small sterilized platinum handle, it was lifted and deposited in the center of the new dish, with the mycelium faced to the culture media. The dishes were then inverted and maintained in plastic bags (in order to avoid contaminations during handling) in B.O.D. chambers, at $25^{\circ} \mathrm{C}$, with no photoperiod.

\section{Monitoring of mycelium growth and vigor of shiitake}

Daily photographs recorded the growth of $L$. edodes strains during incubation until the complete colonization of the Petri dish. The first photograph was taken at the same time of inoculation, but on the next day, establishing, therefore, 24-h cycles. A digital camera attached to a pedestal with an opaque dark background was installed inside the laminar flow. Thus, the position of the camera in relation to the focused platform, whereon the dishes were accommodated, was at a fixed position. The intensity of the fluorescent light reaching and reflecting from the dishes was 550 lux and 50 lux, respectively, as measured by a luximeter (2). Images were photographed with an Agfa digital camera (model ePhoto1280) with the resolution $307 \mathrm{~S}(640 \times 480$ pixels, standard compression), minimal zoom, normal preview, and macro automatic focus. All other settings were standard. The images were analyzed with the freeware UTHSCSA ImageTool, v. 2.0, 1997 (University of Texas Health Science Center, San Antonio, Texas, USA).

\section{Determination of the area of micelial growth}

The files containing the photographs were opened in a personal computer with Agfa PhotoWise (camera accessory); in each photograph, the colony was copied as a quadrilateral image and then image-analyzed in the ImageTool. Image analysis consisted on the identification of objects that could be geometrically delimitated. The objects should be comprised of a continuous region with an equal tonality. Images were analyzed in gray scale with levels that could vary from 0 (black) to 255 (white). Thresholding was performed manually for each image. Seven repeats were performed for each treatment. Images were analyzed separately for area $\left(\mathrm{mm}^{2}\right)$ and vigor, depicted by the mean gray level. The mean and standard deviations of both measures were stored in a Microsoft Excel spreadsheet.

\section{Statistical methods}

It was conducted completely randomized factorial experiments (four strains and four culture media), with seven replications per treatment. Nonlinear regressions models were used to fit the mycelium growth kinetics of the L. edodes. After the selection procedure, the best model was choice using the residual sum of squares. The Nonparametric analysis of variance was carry out (Kruskal-Wallis test) to compare the instantaneous velocity growth (taking the first derivate of the deterministic component of the model) between treatments, by the Student-Newman-Keuls test. The procedure used as follows: 
if there is (no) statistical difference between the parameters of two treatments, then we (don't) have the statistical difference between the instantaneous velocity growth.

\section{RESULTS AND DISCUSSION}

The model that best explained the growth kinetics of $L$. edodes strains in solid culture media has, in its deterministic component, the exponential of a Gompertz function (12):

$\mathrm{Y}_{\mathrm{ij}}=\exp \left\{\alpha_{\mathrm{j}} \exp \left[-\exp \left(\beta_{\mathrm{j}}-\gamma_{\mathrm{j}} \mathrm{X}_{\mathrm{ij}}\right)\right]\right\}+\mathrm{e}_{\mathrm{ij}}$ where $\mathrm{Y}_{\mathrm{ij}}$ is the area of growth $\left(\mathrm{mm}^{2}\right) ; X_{\mathrm{ij}}$ is the time in days; $\alpha, \beta$, and $\gamma$ are the parameters model; $\mathrm{e}_{\mathrm{ij}}=$ random component; the index $i$ and $j$ are related to the observations and treatments, respectively.

Filamentous fungi growth was determined by the $\alpha, \beta$, and $\gamma$ parameters, in which interacted during the colonization of the culture media, unleashing distinct behaviors among strains as regards culture media, as was observed by Regina (13) while studying their growth kinetics in culture media made of sawdust and sugar-cane bagasse supplemented with bran in various proportions. Growth curves of L. edodes mycelium in different culture media are depicted in Fig. 1.
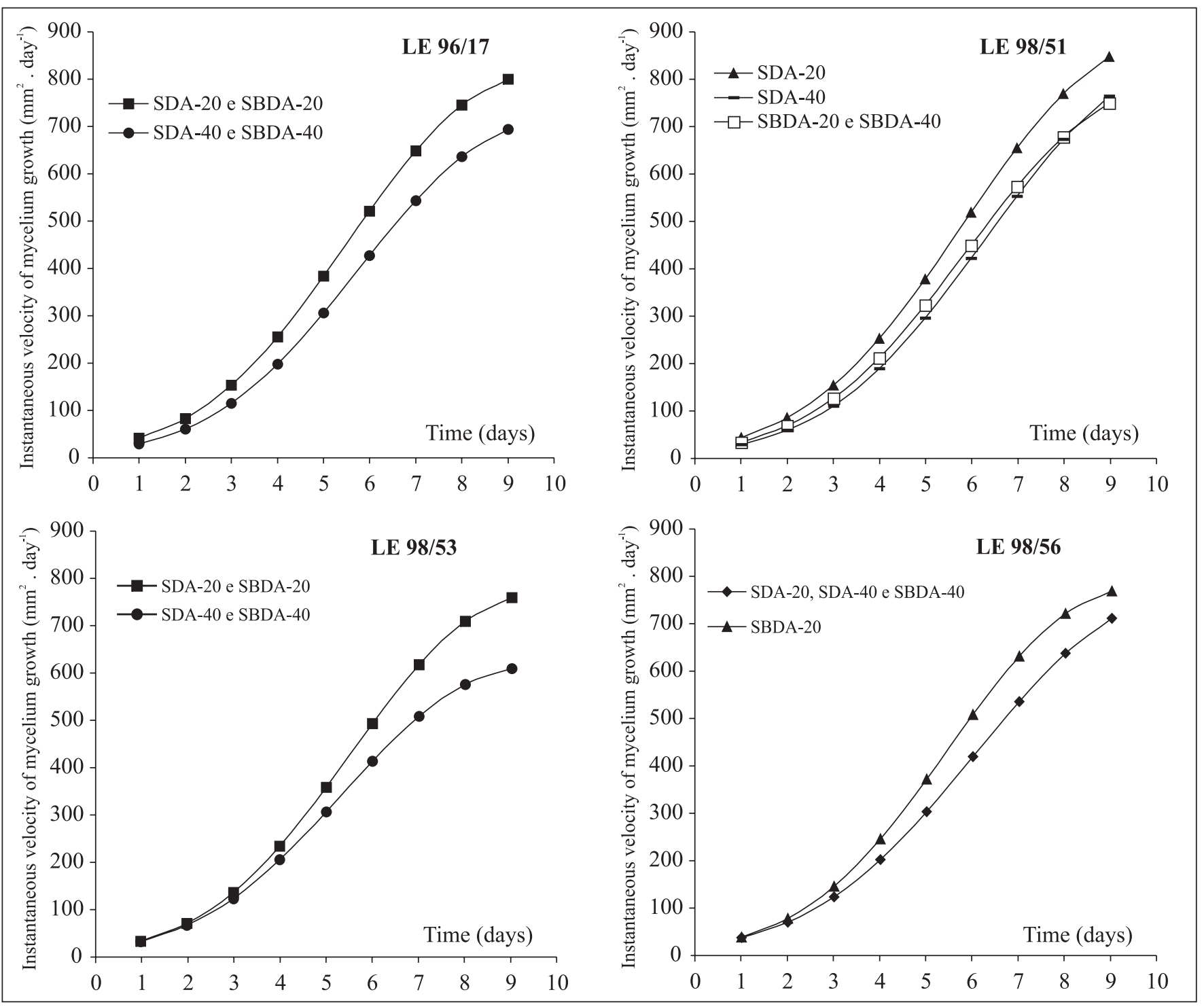

Figure 1. Instantaneous velocity growth of L. edodes mycelium strains LE 96/17, 98/51, 98/53, and 98/56 in the culture media SDA20, SDA-40, SBDA-20, and SBDA-40 (radial growth in Petri dishes). In all curves plotted there are statistical difference between the instantaneous velocity growth the parameters of the treatments. 
When the instantaneous velocity curves of mycelium growth of all strains are compared in function of culture media (Fig. 1), we observed that LE 98/51 presented higher instantaneous velocities in the SDA-20 media along time, followed by the strain LE 96/17 in SDA-20 and SBDA-20 media, which did not show significant differences between them, as depicted in Fig. 1. In the other hand, strains LE 96/17 and LE 98/53 presented, in comparison, inferior instantaneous velocities in the SDA-40 and SBDA-40 media. Variations in growth speed as a function of strain have been described by Boyle (1), while studying $L$. edodes growth-limiting factors.
Similarly, strain effects were also reported by others authors $(15,20)$ studying the interaction of $L$. edodes strains with culture media constituents. The same was observed for biomass production in liquid media (19). Inter-strain metabolic differences can cause significant differences in the capability of nitrogen utilization (7). Nitrogen is a limiting factor for the mycelium growth of $L$. edodes (1). However, there is a maximal threshold, after what a decrease in growth occurs (16).

The terminology "vigor" is herein being proposed and quantified digitally, although it has already been used by other authors $(8,14,18)$. Vigor has albeit been measured by the
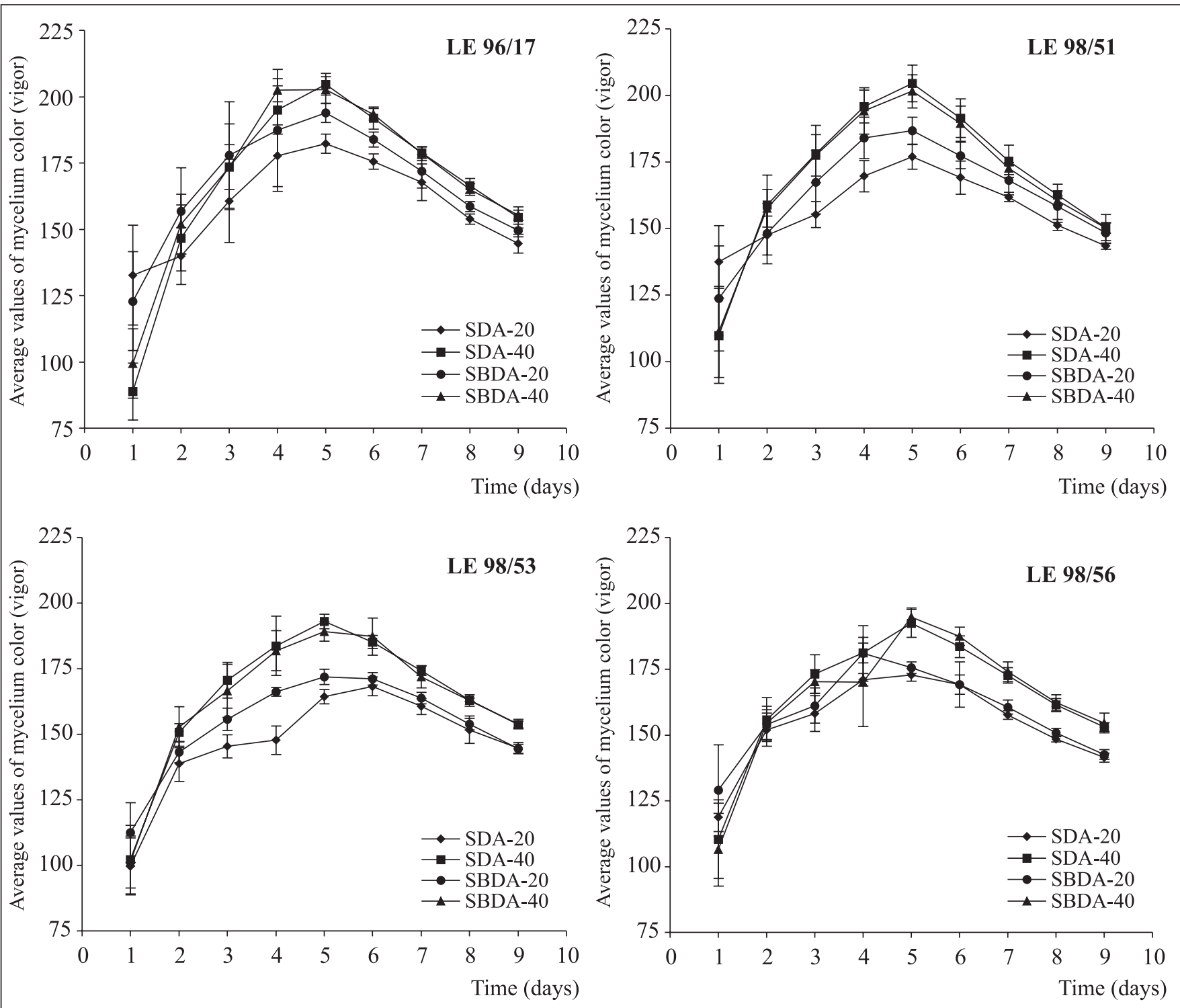

Figure 2. Average values of mycelium color in gray scale (vigor) during mycelium growth of strains LE 96/17, 98/51, 98/53, and 98/ 56 in function of culture media. 
subjective criteria of scores. Thus, we propose to express vigor as a continuous variable obtained by digitalized images based on the mycelial density (reflecting directly the biomass) and mycelium age. Mycelium age can be expressed in function of tonality changes along time, which frequently escape the naked eye but are detectable by digital analysis.

The behavior of vigor was similar for all strains (Fig. 2). In the first day, vigor was smaller, probably due to the brownish area present on the back of the disc, used to inoculate the culture media with $L$. edodes. Starting from the $2^{\text {nd }}$ day, we observed a progressive increase in the mean values, peeking between $4^{\text {th }}$ and $5^{\text {th }}$ days. Vigor varied as a function of the applied culture media, with exception of strains LE 98/53 in media SDA-20, wherein the maximal value occurred at $6^{\text {th }}$ day. After they reached maximal vigor, we registered a decline until the last day. 95\% confidence intervals evinced a decrease in amplitude of measures beginning from the day of maximal vigor. The results allowed us to verify how strains develop they increase in vigor. However, vigor decreases after $5^{\text {th }}$ day, probably due to the ageing of the mycelium in the colony center, a fact that shifts the metabolism of the fungus, yielding vacuoles (17) and exudates (5). Such facts may thus contribute to the tonality changes of the mycelium, which are not detectable by naked eye.

Digital analysis permits the non-subjective evaluation of vigor of growth of strains. Apart from the evaluation on a Petri dish, digital analysis could also be used for the assessment of growth in sawdust, which has been associated with good fruiting of L. edodes (18).

\section{CONCLUSIONS}

The kinetics of mycelium growth, as measured by the mycelium area, regardless of strain and substrate, has as a deterministic component an exponential function of Gompertz.

The vigor of different $L$. edodes strains determined in vitro by digitalized image decreases from the fifth day of incubation, independently of strain and culture media. The velocity of growth of L. edodes strains was lower in enriched culture media, while vigor was higher.

Digital monitoring permits a objective evaluation of the growth kinetics of $L$. edodes in vitro.

\section{ACKNOWLEDGEMENT}

This study was supported with grants from Fundação de Amparo à Pesquisa e Extensão do Estado de São Paulo (FAPESP proc. 98/07726-5), Conselho Nacional de Desenvolvimento Científico e Tecnológico (CNPq) and Módulo de Cogumelos Unesp/ FCA/ Botucatu, Brazil.

\section{RESUMO}

\section{Monitoramento digital do crescimento e vigor do shiitake (Lentinula edodes (Berk.) Pegler) em meio de cultura}

Avaliou-se o crescimento e vigor das linhagens LE 96/17, LE 98/51, LE 98/53 e LE 98/56 de Lentinula edodes (Berk) Pegler em diferentes composições de meio de cultura. As linhagens foram provenientes da Micoteca do Módulo de Cogumelos da Faculdade de Ciências Agronômicas, Unesp, Campus de Botucatu. Os isolados foram obtidos por propagação vegetativa, pela transferência asséptica do micélio para o meio de cultura de extrato de serragem-dextrose-ágar. O crescimento e vigor do micélio foi fotografado diariamente com uma câmera digital, durante a incubação, até a colonização total da placa de Petri. As imagens foram analisadas pelo programa UTHSCSA ImageTool (freeware), versão 2.0, desenvolvido pela University of Texas Health Science Center, San Antonio, Texas. O modelo estatístico que melhor explicou a cinética de crescimento miceliano em área $\left(\mathrm{mm}^{2}\right)$, das linhagens de cogumelos L. edodes, tem como componente determinístico a exponencial de uma função Gompertz. O vigor, avaliado através da cor do micélio (em escala de tons do cinza), revelou um comportamento similar entre as linhagens, com valor máximo entre o $4^{\circ}$ e $5^{\circ}$ dia e, em seguida apresentou declínio. Em meios de cultura mais enriquecidos, a velocidade de crescimento das linhagens de L. edodes foi menor e o vigor maior. $O$ monitoramento digital permite uma avaliação objetiva do crescimento e vigor do L. edodes in vitro.

Palavras-chave: Lentinula edodes, shiitake, substratos, crescimento miceliano, linhagens

\section{REFERENCES}

1. Boyle, C.D. Nutritional factors limiting the growth of Lentinula edodes and other white-rot fungi in wood. Soil Biol. Biochem., 30, 817-23, 1998.

2. Busselli, M. Tudo sobre fotografia. 5.ed. Pioneira, São Paulo, 1990, p.224.

3. Celso, P.G. Interações entre Agaricus bisporus e microrganismos termófilos isolados do substrato de cultivo do cogumelo. Araraquara, 1999. 84p. (Thesis. Instituto de Química, Unesp).

4. Chang, S.T.; Miles, P.G. Edible mushrooms and their cultivation. Boca Raton, Florida, 1989, p.189-223.

5. Griffin, D.H. Growth. In: Fungal physyology. 2.ed. Wiley-Liss, New York, 1994, 458p.

6. Khan, S.M.; Mirza, J.H.; Khan, M.A. Studies on shiitake mushrooms (Lentinula edodes (Berk.) Pegler. XIII INTERNATIONAL CONGRESS ON THE SCIENCE AND CULTIVATION OF EDIBLE FUNGI, 1991, Dublin, p.503-8

7. Kurtzman, J.R.; Zadrazil, F. Physiological and taxonomic considerations for cultivation of Pleurotus mushrooms. In: CHANG, S.T.; QUIMIO, T.H. Tropical mushrooms: biological nature and cultivation methods. The Chinese University Press, Hong Kong, 1982, 493p. 
8. Marino, R.H. Produtividade do Pleurotus sajor-caju (Fr.) Sing. em função dos métodos de isolamento e produção de inoculantes. Araraquara, 1997. 134p. (Thesis. Instituto de Química, Unesp).

9. Nascimento, J.S.; Marino, R.H.; Regina, M.; Kuramae, E.E.; EIRA, A.F. Caracterização molecular de linhagens do cogumelo shiitake (Lentinula edodes (Berk.) Pegler). XXI CONGRESSO BRASILEIRO DE MICROBIOLOGIA, Foz do Iguaçu, 2001, p.350.

10. Pegler, D.N. The genus Lentinula (Tricholomataceae tribe Collybieae). Sydowia, 36, 227-39, 1983.

11. Prosser, J. I. Kinetics of filamentous growth and branching. In: GOW, A.R., GADD, G.M. The growing fungus. Chapman \& Hall, London, 1994, p.301-35.

12. Ratkowsky, D.A. Handbook of nonlinear regression models. Marcel Decker, New York, 1990, 241p.

13. Regina, M. Cinética do crescimento miceliano de Lentinula edodes (Berk.) Pegler em bagaço de cana-de-açúcar e serragem de eucalipto. Botucatu, 2001, 87p. (Thesis. Faculdade de Ciências Agronômicas, Unesp).

14. Rossi, I.R. Suplementação de bagaço de cana-de-açúcar para cultivo axênico do cogumelo shiitake [Lentinula edodes (Berk.)
Pegler]. Jaboticabal, 1999, 129p. (Thesis. Faculdade de Ciências Agrárias e Veterinárias, Unesp).

15. Royse, D.J.; Bahler, C.C. Effects of genotype, spawn run time and substrate formulation on biological efficiency of shiitake. Appl. Environ. Microbiol., 52, 1425-7, 1986.

16. Song, C.H.; Cho, K.Y.; Nair, N.G. A synthetic medium for the production of submerged cultures of Lentinus edodes. Mycologia, 79, 866-76, 1987.

17. Stanier, R.Y.; Doudoroff, M.; Adelberg, E.A. O mundo dos micróbios 2. ed. Edgard Blücher, São Paulo, 1969, 741p.

18. Tan, Y.H.; Chang, S.T. Effect of growth regulators, enzyme inhibitors and stimulatory additives on the vegetative development and frutification of Lentinus edodes. XII INTERNATIONAL CONGRESS ON THE SCIENCE AND CULTIVATION OF EDIBLE FUNGI, Braunschweig, 1987, p.267-77.

19. Tan, Y.H., Moore, D. Convenient and effective methods for in vitro cultivation of mycelium and fruiting bodies of Lentinus edodes. Mycol. Res., 96, 1077-84, 1992.

20. Worral, J.J.; Yang, C.S. Shiitake and oyster mushroom production on apple pomace and sawdust. HortScience, 27, 1131-3, 1992. 